$62^{\text {th }}$ INTERNATIONAL ATLANTIC ECONOMIC CONFERENCE

Philadelphia, Pennsylvania, October 5-8, 2006

\title{
The Influence of Monetary and Fiscal Policies on Social Welfare
}

\author{
Professor Moisa ALTAR,
}

Doctoral School of Finance and Banking, Academy of Economic Studies, 6

Piata Romana, sect. 1, Bucharest, Romania

e-mail:maltar@ase.ro; maltar@starnets.ro

http://www.dofin.ase.ro

phone: +40-744-529831

fax: $+40-21-3129549$

and

Professor Judita SAMUEL

Romanian - American University, Bucharest, 1, Bd. Expozitiei, sect. 1, Bucharest, Romania

e-mail: jsamuel47@yahoo.com

phone: +40-723-371036

JEL Clasification : C 61, D 99,E 31, E 41, E 62, E 63, H 62, H 63, O 41.

Macro focus 


\begin{abstract}
The paper analyses the way in which monetary and fiscal policy influences the performances of economic growth and social welfare.. The analysis is made on the basis of a dynamic model with discrete variables . The model is with a representative private agent and a government sector consisting of a consolidated fiscal authority and central bank. Households, in each period, decide about consumption., investment in physical capital, and financial investment in government bonds. The model is built in such a way that satisfaction of the budget constraint of the representative household implies satisfaction of the budget constraint of the government.

The model has two state variables: the first is private wealth (consisting of money, bonds and physical capital), and the second is physical capital. The decision variables are: private nominal consumption , social nominal consumption and the amount of bonds bought by the private agent.

The optimality conditions are obtained by using the Maximum Principle for discrete dynamic systems. A qualitative analysis of the optimal trajectories is performed, on the basis of the information provided by the Maximum Principle, concerning the dynamics of the dual variables .

Finally, we analyze the influence of several monetary and fiscal decisions on the optimal trajectories of the model.
\end{abstract}

JEL Clasification : C 61, D 99,E 31, E 41, E 62, E 63, H 62, H 63, O 41. Keywords: Economic Growth, Monetary Policy, Fiscal Policy, Fiscal Solvency, Maximum Principle 


\section{Introduction}

In recent years relative effectiveness of monetary and fiscal policy action on economic growth an on social welfare has been debated by both economists and policy makers.

The traditional optimal currency areas literature pointed out long ago that, in a monetary union, fiscal policy has to play a more important role in cyclical stabilization given the loss of national monetary independence. This is particularly the case if shocks are not perfectly correlated across frontiers. Fiscal flexibility, together with budgetary discipline and co-ordination, has come to be seen as a central pillar of fiscal policy in a currency area. The Stability and Growth Pact (SGP) has been the operational response of EU countries to the quest for budgetary discipline in EMU.

Recent theoretical and empirical developments have shed new light on the 'old' issue of the interaction between monetary and fiscal authorities.

There are numerous studies, both theoretical and empirical, analyzing the relation between inflation and long-run growth.

In the past decade the development of the endogenous growth literature pioneered by Romer (1986), Lucas (1988), and Rebelo (1991) has enhanced our understanding about how an economy's growth performance can be affected by public policies. For instance, Barro (1990) and King and Rebelo (1990) study the effects of fiscal policies, such as government spending and taxation, on economic growth. The general conclusion is that taxation adversely affects long-run growth performance and that the quantitative impacts are much larger than those found in exogenous growth models. Chari, Jones, and Manuelli (1995) and van der Ploeg and Alogoskoufis (1994) examine the effects of monetary policies, such as changes in the growth rates of nominal money supplyliter, on long-run real activity. These authors find support for the conventional wisdom that inflation and long-run growth are inversely related. These studies also represent an advance in our understanding of the impact of alternative policies on inflation and growth.

Recently economists have been paying increasing attention to a dynamic general equilibrium approach to the theory of price level that is often called the fiscal theory of the price level, or FTPL. This way of thinking emphasizes the role of fiscal and monetary policy in determining the risk and return properties of government liabilities. It is particularly useful in analyzing proposals for large-scale institutional changes that imply shifts in monetary and fiscal policies.

First, the literature on the monetary implications of fiscal (in)discipline, which originates with Sargent and Wallace (1981), emphasizes that, to the extent that the path of a government's fiscal deficit is predetermined and unsustainable, then monetary policy and the price level are no longer exogenous to it. A similar point arises in the context of the Fiscal Theory of the Price Level (Leepe, 1991, and Woodford, 1995). However, in these frameworks the goals of fiscal policy are not explicitly discussed, and do not 
include macro stabilization. Nevertheless, the scenario analysed by Sargent and Wallace has surely been influential in motivating the emphasis on fiscal discipline as a prerequisite for monetary stability, which has been placed in the Treaty of Maastricht and, in particular, on the design of the criteria for admission to the third phase of EMU.

A general survey of these issues in neoclassical models is in Chari and Kehoe (1999). Issues of coordination also appear in models of the inflation tax or seigniorage policy (Barro, 1979; Lucas and Stokey, 1983). In particular, Alesina and Tabellini (1987) study the desirability of fiscal and monetary policy coordination in a seigniorage model where monetary policy has no stabilization features and (expansive) fiscal policies affects output negatively.

\section{The Structure of the Economy}

In our model economy there is a representative household and a government. In each period, the government issues currency $M_{t}$, nominal debt $B_{t}$ and fix a distortionary rate of income tax $\tau_{t}$ to finance the level of public consumption $g_{t}$.

The sequence of government budget constraints is the following:

$g_{t}+i_{t} B_{t}=\tau_{t} f\left(k_{t}\right)+M_{t+1}-M_{t}+B_{t+1}-B_{t}$

where $i_{t}$ is the nominal interest rate paid on debt issued by the government.

Technology takes the form:

$y=f(k)$

where $\mathrm{y}$ is output and $\mathrm{k}$ is private capital input.

The production function of the representative agent satisfies the folowing conditions:

$$
f^{\prime}(\cdot)>0 \text { and } f^{\prime \prime}(\cdot)<0
$$

We will assume that the economy is closed and the markets are perfectly competitive and all prices are flexible.

Equilibrium on the goods market is:

$y_{t}=f\left(k_{t}\right)=c_{t}+g_{t}+h_{t}$

where $c_{t}$ is consumption and $h_{t}$ is investment.

The dynamic equation of private capital is the following: 
$k_{t+1}=k_{t}+h_{t}$

or

$k_{t+1}=k_{t}+f\left(k_{t}\right)-c_{t}-g_{t}$

and $h_{t}=k_{t+1}-k_{t}$

respectively.

Without loss of generality, we assumed that the depreciation rate of capital is zero.

The initial stock of currency, $M_{0}$, the initial debt liabilities $B_{0}\left(1+i_{0}\right)$, and the initial stock of private capital, $k_{0}$ are given. A government policy is, therefore, a specification of $\left\{M_{t}, B_{t}, \tau_{t}, g_{t}\right\}$ for $t \geq 0$.

Each period, the representative household faces the following budget constraint:

$$
c_{t}+h_{t}+M_{t}+B_{t+1}=\left(1-\tau_{t}\right) f\left(k_{t}\right)+M_{t}+\left(1+i_{t}\right) B_{t}
$$

or

$$
c_{t}+k_{t+1}-k_{t}+M_{t}+B_{t+1}=\left(1-\tau_{t}\right) f\left(k_{t}\right)+M_{t}+\left(1+i_{t}\right) B_{t}
$$

We will denote by $Z_{t}$ the wealth of the representative household:

$$
\begin{aligned}
& Z_{t}=M_{t}+B_{t}+k_{t} \\
& g_{t}+i_{t} B_{t}=\tau_{t} f\left(k_{t}\right)+Z_{t+1}-Z_{t}+k_{t} \\
& c_{t}+Z_{t+1}=\left(1-\tau_{t}\right) f\left(k_{t}\right)+Z_{t}+i_{t} B_{t}
\end{aligned}
$$

According to formula (12), it follows that the dynamic equation of the wealth of the representative household is:

$$
Z_{t+1}=Z_{t}+\left(1-\tau_{t}\right) f\left(k_{t}\right)+i_{t} B_{t}-c_{t}
$$

The specific form of the cash constraint is:

$$
c_{t}+g_{t}+h_{t}=M_{t}
$$

or

$$
c_{t}+g_{t}+k_{t+1}-k_{t}=M_{t}
$$


Relationship (15) can also be written as:

$$
k_{t+1}=Z_{t}-B_{t}-c_{t}-g_{t}
$$

As a matter of fact, relationship (16) can be interpreted as the dynamic equation of private capital.

We notice that if the budget constraint of the representative budget (relation (8)), as well as the equilibrium equation (4) are satisfied, then equation (1), which represents the government budget constraints, is satisfied.

We shall suppose that the representative household seeks to maximize a discounted sum of utilities of the following form:

$$
\sum_{t=0}^{\infty} \delta^{t}\left[U\left(\frac{c_{t}}{p_{t}}\right)+V\left(\frac{g_{t}}{p_{t}}\right)\right]
$$

where $U(\cdot)$ and $V(\cdot)$ are increasing, concave functions, and the discount factor satisfies $0<\delta<1$.

We notice in relation (17) that both private consumption and public consumption are deflated by the price level $p_{t}$.

\section{The Model}

With the above observations and notations, the model of the representative household is:

$$
\left\{\begin{array}{l}
\max \sum_{t=0}^{\infty} \delta^{t}\left[U\left(\frac{c_{t}}{p_{t}}\right)+V\left(\frac{g_{t}}{p_{t}}\right)\right] \\
Z_{t+1}=Z_{t}+\left(1-\tau_{t}\right) f\left(k_{t}\right)+i_{t} B_{t}-c_{t} \\
k_{t+1}=Z_{t}-B_{t}-c_{t}-g_{t}
\end{array}\right.
$$

The model (18) is a dynamic model with discrete variables. It contains two state variables , $Z_{t}$ and $k_{t}$, and three decision variables, $c_{t}, g_{t}$ and $B_{t}$.

We assume that, for each time period $t$, the values of $M_{t}, p_{t}$ and $\tau_{t}$ are given exogenously.

To deduce the optimal solution of the model (18), we apply the Maximum Principle for systems with discrete variables (Altar,1976).

The Hamiltonian function of the system is: 
$H_{t}=\delta^{t}\left[U\left(\frac{c_{t}}{p_{t}}\right)+V\left(\frac{g_{t}}{p_{t}}\right)\right]+\psi_{t}^{1}\left[Z_{t}+\left(1-\tau_{t}\right) f\left(k_{t}\right)+i_{t} B_{t}-c_{t}\right]+\psi_{t}^{2}\left[Z_{t}-B_{t}-c_{t}-g_{t}\right]$

We denoted by $\psi_{t}^{1}$ and $\psi_{t}^{2}$ the dual variables.

The optimality conditions are:

$$
\left\{\begin{array}{l}
\delta^{t} U^{\prime}\left(\frac{c_{t}}{p_{t}}\right) \cdot \frac{1}{p_{t}}-\psi_{t}^{1}-\psi_{t}^{2}=0 \\
\delta^{t} V^{\prime}\left(\frac{g_{t}}{p_{t}}\right) \cdot \frac{1}{p_{t}}-\psi_{t}^{2}=0 \\
i_{t} \psi_{t}^{1}-\psi_{t}^{2}=0
\end{array}\right.
$$

and the dynamic equations for the dual variables are:

$\psi_{t-1}^{1}=\psi_{t}^{1}+\psi_{t}^{2}$

$\psi_{t-1}^{2}=\left(1-\tau_{t}\right) f^{\prime}\left(k_{t}\right) \psi_{t}^{1}$

From the above relations it follows:

$\psi_{t-1}^{1}=\left(1+i_{t}\right) \psi_{t}^{1}$

and

$\delta^{t} U^{\prime}\left(\frac{c_{t}}{p_{t}}\right) \cdot \frac{1}{p_{t}}=\left(1+i_{t}\right) \psi_{t}^{1}$

Taking into account that relation (26) is also valid for the period $t-1$, it follows:

$\delta^{t-1} U^{\prime}\left(\frac{C_{t-1}}{p_{t-1}}\right) \cdot \frac{1}{p_{t-1}}=\left(1+i_{t-1}\right) \psi_{t-1}^{1}$ 


\section{Qualitative Analysis}

From relations (26) and (27) and taking into account (25), we obtain the following Euler equation:

$U^{\prime}\left(\frac{c_{t}}{p_{t}}\right)=\frac{1}{\delta} \frac{\frac{p_{t}}{p_{t-1}}}{1+i_{t-1}} U^{\prime}\left(\frac{C_{t-1}}{p_{t-1}}\right)$

or

$U^{\prime}\left(\frac{C_{t}}{p_{t}}\right)=\frac{1}{\delta\left(1+R_{t-1}\right)} U^{\prime}\left(\frac{C_{t-1}}{p_{t-1}}\right)$

where we denoted by $R$ the real interest rate.

Equation (29) emphasizes the fact that the dynamics of the real consumption depends on the relationship between the discount factor and the real interest rate.

In the special case when:

$\delta=\frac{1}{1+R_{t-1}}$

we obtain, from relation 29

$\frac{c_{t}}{p_{t}}=\frac{c_{t-1}}{p_{t-1}}$

or

$c_{t}=\left(1+\pi_{t-1}\right) c_{t-1}$

where $\pi$ represents the rate of inflation.

If the real interest rate is constant:

$R_{0}=R_{1}=\ldots=R_{t-1}=R$

and: 
$\delta=\frac{1}{1+R}$

we obtain:

$c_{t}=\prod_{k=0}^{t-1}\left(1+\pi_{k}\right) \cdot c_{0}$

Relation (31) highlights the fact that, while the real interest rate remains constant and relation (34) is satisfied, the level of real consumption remains constant in time.

Concerning the relationship between private and public consumption , we obtain from the optimality condition:

$V^{\prime}\left(\frac{g_{t}}{p_{t}}\right)=\frac{i_{t}}{1+i_{t}} U^{\prime}\left(\frac{c_{t}}{p_{t}}\right)$

In the particular case when the utility functions $U$ and $V$ are of Bernoulli type:

$U\left(\frac{C_{t}}{p_{t}}\right)=\frac{1}{1-\sigma_{c}}\left(\frac{c_{t}}{p_{t}}\right)^{1-\sigma_{c}}$

$V\left(\frac{g_{t}}{p_{t}}\right)=\frac{1}{1-\sigma_{g}}\left(\frac{g_{t}}{p_{t}}\right)^{1-\sigma_{g}}$

relation (36) becomes:

$\frac{g_{t}}{p_{t}}=\left(\frac{1+i_{t}}{i_{t}}\right)^{\frac{1}{\sigma_{g}}}\left(\frac{c_{t}}{p_{t}}\right)^{\frac{\sigma_{c}}{\sigma_{g}}}$

From relation (39) we deduce that the level of public consumption is lower than the level of private consumption if the following relations are satisfied:

$\sigma_{g}>\sigma_{c}$

and

$\ln \frac{c_{t}}{p_{t}}>\frac{1}{\sigma_{g}-\sigma_{c}} \ln \frac{1+i_{t}}{i_{t}}$ 
Next, we will derive the relations between the size of the private capital, the nominal interest rate, $i$, and the fiscality rate, $\tau$.

From the dynamics equations (22), (24) and (25) of the dual variable we obtain:

$$
\left(1+i_{t}\right) i_{t-1}=\left(1-\tau_{t}\right) f^{\prime}\left(k_{t}\right)
$$

or

$i_{t}=\frac{\left(1-\tau_{t}\right) f^{\prime}\left(k_{t}\right)}{i_{t-1}}-1$

From $i_{t} \geq 0$ we obtain the following condition:

$$
\left(1-\tau_{t}\right) f^{\prime}\left(k_{t}\right) \geq i_{t-1}
$$

Relation (44) expresses the fact that the level of the capital $K_{t}$ has to be chosen in such a way that the marginal productivity, $f^{\prime}\left(k_{t}\right)$, adjusted with the fiscality rate $1-\tau_{t}$, has to be higher than the nominal interest rate, $i_{t-1}$.

From relation (42) we also obtain the following formula, which gives the optimal level of the capital:

$$
K_{t}=\left(f^{\prime}\right)^{-1}\left(\frac{\left(1+i_{t}\right) i_{t-1}}{1-\tau_{t}}\right)
$$

From relation (45), it follows that the level of the private capital increases if the nominal interest rates $i_{t}$ or $i_{t-1}$ decrease, or if the fiscality rate $\tau_{t}$ decreases.

As concerns the optimal level of the stock of nominal government debt, we have the formula:

$$
B_{t}=Z_{t}-M_{t}-\left(f^{\prime}\right)^{-1}\left(\frac{\left(1+i_{t}\right) i_{t-1}}{1-\tau_{t}}\right)
$$

Formula (46) points out the fact that the size of the stock of nominal government debt depends on private wealth $Z_{t}$, on the size of the stock of money, $M_{t}$, on the nominal interest rates, $i_{t-1}$ and $i_{t}$ and on the fiscality rate, $\tau_{t}$.

To deduce the dynamic equation of the nominal interest rate, we will take into account the relation:

$$
f\left(k_{t}\right)=M_{t}
$$

It follows: 
$k_{t}=f^{-1}\left(M_{t}\right)$

Using relation (47), from (43) it follows:

$i_{t}=\frac{\left(1-\tau_{t}\right) f^{\prime}\left(f^{-1}\left(M_{t}\right)\right)}{i_{t-1}}-1$

From relation (48), which represents the dynamic equation of the nominal interest rate, it follows that $i_{t}$ decreases if $M_{t}$ increases or if the fiscality rate $\tau_{t}$ increases.

Finally, we will show that if relation (30) is satisfied, which insures that the levels of real private consumption are equal in the periods $\mathrm{t}-1$ and $\mathrm{t}$ (according to relation (31)) and if the nominal interest rate satisfies the condition

$i_{t-1}=i_{t}$

then we also have

$\frac{g_{t-1}}{p_{t-1}}=\frac{g_{t}}{p_{t}}$

Indeed, from (36) we obtain:

$V^{\prime}\left(\frac{g_{t}}{p_{t}}\right)=\frac{i_{t}}{1+i_{t}} U^{\prime}\left(\frac{c_{t}}{p_{t}}\right)$

and

$V^{\prime}\left(\frac{g_{t-1}}{p_{t-1}}\right)=\frac{i_{t-1}}{1+i_{t-1}} U^{\prime}\left(\frac{C_{t-1}}{p_{t-1}}\right)$

Because relation (30) ensures that

$\frac{c_{t}}{p_{t}}=\frac{c_{t-1}}{p_{t-1}}$,

relation (49) implies that (50) is satisfied. 


\section{Transversality Conditions}

For the optimal trajectories the Maximum Principle provides the following transversality conditions:

$\lim _{T \rightarrow \infty} \psi_{T}^{1} Z_{T}=0$
$\lim _{T \rightarrow \infty} \psi_{T}^{2} k_{T}=0$

From the dynamic equation (25), it follows:

$\psi_{t}^{1}=\frac{1}{1+i_{t}} \psi_{t-1}^{1}$

or

$\psi_{T}^{1}=\prod_{k=1}^{T}\left(\frac{1}{1+i_{k}}\right) \psi_{0}^{1}$

In this case, relation (51) becomes:

$\lim _{T \rightarrow \infty}\left(\prod_{k=1}^{T} \frac{1}{1+i_{k}}\right) Z_{T}=0$

If the nominal interest rate is constant:

$i_{k}=i_{k-1}=i \quad, \quad \forall k \geq 1$

then relation (54) becomes:

$\lim _{T \rightarrow \infty}\left(\frac{1}{1+i}\right)^{T} Z_{T}=0$

This means that the sequence $\left\{Z_{t}\right\}_{t \in N}$ should increase slower than the sequence $\left\{(1+i)^{t}\right\}_{t \in N}$.

Taking into account the structure of the private wealth, $Z_{T}$, which is

$Z_{T}=M_{T}+B_{T}+K_{T}$, 
from relation (56), it follows:

$\lim _{T \rightarrow \infty}\left(\frac{1}{1+i}\right)^{T} M_{T}=0$

$\lim _{T \rightarrow \infty}\left(\frac{1}{1+i}\right)^{T} B_{T}=0$

$\lim _{T \rightarrow \infty}\left(\frac{1}{1+i}\right)^{T} R_{T}=0$

Next, we will take a look at the information provided by the transversality condition (52).

From relations (22) and (24), it follows:

$\psi_{t}^{2}=\frac{i_{t}}{\left(1-\tau_{t}\right) f^{\prime}\left(k_{t}\right)} \psi_{t-1}^{2}$

which, taking into account (42). becomes:

$\psi_{t}^{2}=\frac{i_{t}}{\left(1+i_{t}\right) i_{t-1}} \psi_{t-1}^{2}$

The solution of equation (62) is

$\psi_{T}^{2}=\prod_{k=1}^{T}\left(\frac{i_{k}}{\left(1+i_{k}\right) i_{k-1}}\right) \psi_{0}^{2}$

If relation (55) is satisfied, relation (63) becomes:

$\psi_{T}^{2}=\left(\frac{1}{1+i}\right)^{T} \psi_{0}$

and the transversality condition (52) will coincide with (58). So, if the monetary policy ensures a constant nominal interest rate , the transversality condition (52) is automatically satisfied. 


\section{Conclusions}

We studied in this paper a discrete time economic growth model, having elements of monetary and fiscal policy. We obtained the dynamic equation of private consumption and of public consumption. The dynamics depend on the nominal interest rate and on the inflation rate. If the real interest rate coincides with the subjective discount rate, then optimal consumption is constant on the whole horizon. The real demand for money is also constant. 


\section{References}

Artis, M. J. and Buti, M. (2001) - 'Setting Medium Term Fiscal Targets in EMU'. in Brunila et al. (eds), pp. 185-203

Barro, R. J. (1974), “Are government Bonds Net Wealth?”, Journal of Political Economy, vol 82, no 6, pp 1095-1117

Barro, R. J. (1981), “Output Effects of Government Purchases”, Journal of Political Economy, vol 89, no. 6, pp. 1086-1121

Barro, R.J., (1990), “Government Spending in a Simple Model of Endogenous Growth”, Journal of Political Economy 98, S103-S125

Beetsma, R. and Uhlig, H. (1999) - "An Analysis of the Stability and Growth Pact" Economic Journal, Vol. 109, No. 4, pp. 546-71

Benigno, P. and M. Woodford (2005), "Inflation Stabilization and Welfare: The Case of a Distorted Steady State", Journal of the European Economic Association, 3, 6, 1185-1236

Blanchard, O. (2000) - 'Commentary: Fiscal Policy in an Era of Surpluses: Economic and Financial Implications'. Federal Reserve Bank of New York - Economic Policy Review, Vol. 6, No. 1, pp. 69-74

Buti, M., Roeger, W. and in’t Veld, J. (2001) - 'Monetary and Fiscal Policy Interactions under a Stability Pact’. EUI Working Papers, ECO No. 8

Calvo, G.A., (1983), “Staggered Prices in a Utility Maximizing Framework”, Journal of Monetary Economics, 12,3,983-998

Calvo, G.A., (1985), "Macroeconomic Implications of the Government Budget Constraint: Some Basic Considerations”, Journal of Monetary Economics, 15,95112

Canzoneri, M.B., C. Nolan and A. Yates, (1997), "Mechanisms for Achieving Monetary Stability: Inflation Targeting versus the ERM”, Journal of Money, Credit and Banking, 29(1),44-60

Canzoneri, M.B., R.E. Cumby and B.T. Diba, (2001), "Is the Price Level Determined by the Needs of the Fiscal Solvency?”, American Economic Review, forthcoming 
Chadha, J. S., N. Janssen and C. Nolan (2001), "Productivity and Preferences in a Small Open Economy”, The Manchester School, vol 69, pp 57-80

Chadha, J.S. and C. Nolan (2007), "Optimal Simple Rules for the Conduct of Monetary and Fiscal Policy", Journal of Macroeconomics, forthcoming

Chari, V.V. and P.J. Kehoe (1999), "Optimal Fiscal and Monetary Policy", in Handbook of Macroeconomics, vol 1C, edited by John Taylor and Michael Woodford, North-Holland, National Bureau of Economic Research

Christiano, L. J., and T. J. Fitzgerald (2000), "Understanding the Fiscal Theory of the Price Level”, Federal Reserve Bank of Cleveland Economic Review, vol 36, no 2, pp 1-37

Clarida, R., Gali, J. and Gertler, M. (1999) - 'The Science of Monetary Policy: A New Keynesian Perspective'. Journal of Economic Literature, Vol. XXXVII, pp. 1661707

Diaz-Gimenez, J., G. Giovannetti, R. Marimon, P. Teles (2006), "Nominal Debt as a Burden on Monetary Policy", Bank of Portugal Working Paper

Dixit, A. and Lambertini, L. (2000a) - 'Symbiosis of Monetary and Fiscal Policies in a Monetary Union'. Working Paper, Princeton/UCLA, March

Dixit, A. and Lambertini, L. (2000b) - 'Fiscal Discretion Destroys Monetary Commitment'. Working Paper, Princeton/UCLA, August

Dixit, A. and Lambertini, L. (2000c) - 'Monetary-Fiscal Policy Interactions and Commitment Versus Discretion in a Monetary Union'. Working Paper, Princeton/UCLA, August

Ellison, M. and N. Rankin (2005), "Optimal Monetary Policy when Lump-Sum Taxes are Unavailable: A Reconsideration of the Outcomes under Commitment and Discretion", Journal of Economics, Dynamics and Control

Giannoni M. P., and M. Woodford (2002), "Optimal Interest Rate Rules 1: General Theory", NBER Working Paper No. 9419

Hamilton, J.D., and M.A. Flavin, (1986), "On the Limitation of Government Borrowing: A Framework for Empirical Testing”, American Economic Review 76,4,808-819

Hamilton, J.D., and M.A. Flavin, (1986), "On the Limitation of Government Borrowing: A Framework for Empirical Testing”, American Economic Review 76,4,808-819 
King, R.G. and S. Rebelo, (1990), "Public Policy and Economic Growth: Developing Neoclassical Implications”, Journal of Political Economy 98, S126-S150

Kocherlakota, N. and C. Phelan, (1999), "Explaining the Fiscal Theory of the Price Level”, Quarterly Review, Federal Reserve Bank of Minneapolis 23,4,14-23

Krusell, P., F. Martin and J.-V. Rios-Rull (2003), "On the Determination of Government Debt", University of Pennsylvania

Leeper, E., (1991), “Equilibria Under ‘Active’ and 'Passive’ Monetary Policies”, Journal of Monetary Economics, 27,1,129-147

Leith, Campbell, and Wren-Lewis, Simon (2000) `Interactions between monetary and fiscal policy rules`. The Economic Journal, 110 March

Lucas, R.E., Jr., (1988), “On the Mechanics of Economic Development”, Journal of Monetary Economics 22, 3-42

Lucas, R.E., JR. and N.L. Stokey (1983), "Optimal Fiscal and Monetary Theory in an Economy without Capital", Journal of Monetary Economics 12, 55-93

Marimon. R., J. P. Nicolini and P. Teles, 2003, "Inside-Outside Money Competition", Journal of Monetary Economics 50, 1701-1718

McCallum, B.T.,(1984), “Are Bond- financed Deficits Inflationary? A Ricardian Analysis”,The Journal of Political Economy, Volume 92, Issue1,123-135

McCallum, B.T., (2001), "Indeterminacy Bubbles and the Fiscal Theory of Price-Level Determination”, Journal of Monetary Economics, 47,1,19-30

Nicolini, J. P. (1998), "More on the Time Inconsistency of Optimal Monetary Policy", Journal of Monetary Economics 41, 333-350

Obstfeld, M. and K. Rogoff, (1983), "Speculative Hyperinflations in Maximizing Models: Can We Rule Them Out?”, Journal of Monetary Economics, 91 ,4, 675687

Obstfeld, M. (1997), "Dynamic Seigniorage Theory: An Explanation", Macroeconomic Dynamics 1, 3, 588-614

Palivos, T. and C.K. Yip, (1995), "Government Expenditure Financing in an Endogenous Growth Model”, Journal of Money, Credit and Banking 27, 1159-1178

Ramsey, F. P. (1927), "A Contribution to the Theory of Taxation" , The Economic Journal Vol. 37, No.145 (Mar. 1927), pp. 47-61 
Rebelo, S., (1991), "Long Run Policy and Long Run Growth”, Journal of Political Economy 99, 500-521

Romer, P.M., (1996), “Increasing Returns and Long-Run Growth”, Journal of Political Economy 94, 1002-1037

Sargent, T. J. and N. Wallace(1981) “Some Unpleasant Monetarist Arithmetic”, Federal Reserve Bank of Minneapolis Quaterly Review, vol 5, no3, pp1-17

Schmitt-Grohe, S. and M. Uribe (2002), "Optimal Fiscal and Monetary Policy under Sticky Prices", NBER Working Paper W9220

Sims, C., (1994), “A Simple Model for the Study of the Price Level and the Interaction of Monetary and Fiscal Policy”, Economic Theory 4,3,381-399

Sims, C., (1999), “The Precarious Fiscal Foundations of EMU”, Der Economist $147,4,415-436$

Turnovsky, S.J., (1992), “Alternative Forms of Government Expenditures Financing: A Comparative Welfare Analysis”, Economica 59, 23-52

van Aarle, B., Engwerda, J. C., Plasmans, J. E. J. and Weeren, A. (2000) - 'Monetary and Fiscal Policy Design under EMU: A Dynamic Game Approach’. CESifo Working Paper No. 262

Woodford, M. (1995) - 'Price Level Determinacy Without Control of a Monetary Aggregate’. Carnegie-Rochester Conference Series on Public Policy, Vol. 43, pp. $1-46$

Woodford, M., (2001), "Fiscal Requirements for Price Stability”, Journal of Money, Credit and Banking 33,3,669-728

Woodford, M. , (2003), "Interest and Prices: Foundations of a Theory of Monetary Policy", Princeton University Press 